\title{
NALLD NEWS
}

During the month of April, 1980, NALLD sponsored a series of interesting presentations at both the North East Conference on the Teaching of Foreign Languages held at the New York Hilton from April 17-20, 1980, and also at the annual convention of the Association for Educational Communications and Technology (AECT) held in Denver from April 21-24, 1980.

\section{NORTHEAST CONFERENCE}

\section{New York Hilton}

Ms. Jackie Tanner, Language Laboratory Director at the University of Virginia in Charlottesville managed the NALLD effort at NEC. Topics or modes of presentation at the various NALLD presentations on Saturday afternoon, April 19, 1980, included film, slides, videotapes, and a videodisc demonstration. This is the second year in a row that Jackie has arranged the well attended NALLD presentations at NEC. Next year's NEC will again be in New York from April 30th to May 2nd, 1981.

\section{ASSOCIATION FOR EDUCATIONAL COMMUNICATIONS AND TECHNOLOGY}

Denver, Co. Convention Center

On Monday morning, April 21, 1980, the sun was shinning glorously in Denver as Professor Jerome Miller of the University of Illinois prepared to address the NALLD group on the latest update to the copyright law. When he finished, there was a standing room only audience, which was just a precursor of the afternoon session on the videodisc. NALLD Executive Secretary, Sam Burgraaf, completed the arrangments for one of the most astounding videodisc demonstrations ever to hit AECT and which scooped the entire convention. Professors Ed Schneider and Junius Bennion of the McKay Institute at Brigham Young University began the session by demonstrating their videodisc used for teaching Spanish. The most astounding presentation of the day, probably of the entire convention, was given by Professors Nicholas Negroponte and Andrew Lippman, members of the Architecture Machine Group at MIT. With an estimated 400 persons crowded into the room, the description of their current project entitled Spatial Data Management System called forth vision of the interactive computer system depicted in the motion picture Space Odyssey 2001. With an estimated 400 or more persons jammed into the room, easily the largest audience in the history of the NALL.D, Negroponte and Lippman graphically demonstrated the versatility of the videodisc and simply amazed the packed audience.

On Tuesday, Professor Mark Seng of the University of Texas gave a nuts and bolts presentation on how to construct an inexpensive slide copier. Mark's talk was such a success that 19 sets of plans for the copier were sold immediately afterwards. NALLD members should note, however that the entire plans for the copier appears in the NALLD Journal, Volume 14 (Number 1).

On Wednesday afternoon, Allen Evans of Ohio State University gave a presentation on rate-controlled speech. Though the audience was small, 
intense interaction developed between the presentors and the audience.

In retrospect, the NAI.LD board members present in both New York and Denver were more than satisfied with the quality of all the presentors and the resultant publicity for the organization. Indeed, for the second year in a row, NALLD scooped the AECT convention. Obviously one might ask "What next?" Can NALLD maintain this tradition of arranging for speakers and presentations which demonstrate not only the leading edge of the latest educational technology, but also some of the more mundane, but useful and every day items such as Mark Seng's inexpensive slide copier? We can, if we can generate more member input to the various program committees; and, if we can encourage the formation of additional NALLD chaplers; and if the organization can, with confidence, call upon individual members in key locations to perform specific tasks; and if we can develop a spirit of cooperation and ready communication between the membership and the Board of Directors. This would allow the organization to call upon individual members in key locations to perform specific tasks, while simultaneously encouraging individual members to communicate their wishes to the Board. The overall convention program direction rests in the hands of the NALLD Vice President, Victor Aulestia, Director of Instructional Media Resources, University of Maryland at Baltimore County, in Catonsville, Maryland 21228. It goes without saying that all the officio and ex-officio members of the Board are available for direct contact from the membership.

\section{FOREIGN LANGUAGE EDUCATION AND TECHNOLOGY CONFERENCE (FLEAT)}

Okura Hotel, Tokyo Japan

August 18-21, 1981.

While in New York for the North East Convention on the Teaching of Foreign Languages, almost the entire NALLD Executive Board of Directors met with representatives of the Japan Travel Bureau to discuss travel arrangements for the conference.

While the occasion of the conference is to commemorate the first century of English language instruction in Japan, the conference has four major objectives:

1. A presentation in one forum of the major works regarding media and technology in foreign language teaching;

2. Interaction between individuals and organizations at all levels engaged in the various aspects of technology and mediated instruction;

3. Development of improved worldwide cooperation between the various professional groups active in the field of foreign language technology; and

4. Production of a proceedings documenting the latest state of the art and emerging technologies.

The following is a description of the various travel itineraries and prices as quoted by Japan Travel Bureau. Please note that the prices are based on the 1980 market and participants should expect an increase of $10-15 \%$ by 1981 . 


\section{Program A}

Land: $\$ 654$ per person (double occupancy); Air: $\$ 845$ GIT - San Francisco/ Tokyo/SFO; Total: $\$ 1,499$

Your stay in Japan begins with an over night in Tokyo before transferring by "Bullet Train" to Kyoto, "the Classic City" and capital of Japan from 793 to 1868. Accommodations for 3 nights. Visit the famed shrines and gardens of Kyoto. A full day excursion to Nara, the ancient capital, will give you a view of Japan in the Edo period. Then travel through the Hakone area, noted for its beautiful mountains and hot springs. Over night in Hakone. Enroute to Tokyo, cruise across Lake Ashi then drive through Hakone Mountains and down along the Pacific coast, stopping in Kamakura, site of the Diabutsu (Great Image of Buddha). Accommodations in Tokyo at the New Okura Hotel while attending the conference. Following the conference a full day excursion is planned to Nikko, the site of breathtaking Kegon Falls and then to the Irohazaka driveway with its 48 hairpin curves. All sightseeing is on private motorcoach with Englishspeaking guides.

\section{Program B}

Land: $\$ 749$ per person (double occupancy); Air: $\$ 845 \mathrm{GIT}$ - San Francisco/ Tokyo/USA; Total: $\$ 1,589$

Identical to Program A except you will fly to Hawaii enroute to Japan where you will spend 3 nights at the Pacific Beach Hotel. Sightseeing included.

\section{Program C (Land for Conference Only)}

Land: $\$ 328$ per person (double occupancy); Air: $\$ 845 \mathrm{GIT}$ - San Francisco/ Tokyo/SFO; Total: $\$ 1,163$

This program is designed for those wishing to take advantage of our land package for the conference only. It includes 7 nights accommodations at the New Okura Hotel and transfers from the airport to the hotel. This gives you complete freedom to plan your own travel within Japan and the Orient. ITBI in New York will be pleased to help with your travel plans.

Program D (Land Program in Tokyo Only. No Sightseeing.)

Land: $\$ 610$ per person (double occupancy); Air: $\$ 845$ GIT - San Francisco/ Tokyo/SFO; Total: $\$ 1,455$

Accommodations at the New Okura Hotel, Tokyo, for 13 nights while attending the conference and post-conference programs plus transfers from/to the airport. This program provides you with maximum flexibility for technical visits and sightseeing.

\section{Program E (Independent Travel)}

We will gladly arrange your independent travel plans. For those wishing to stay in Tokyo for only the duration of the conference, we offer the following: Roundtrip Economy Class air and accommodations for 4 nights at the New Okura Hotel, August 17 through August 20. 
Current Economy Class air fare San Francisco/Tokyo/San Francisco $\$ 1,104.00$ (As of April 1980)

Accommodation for 4 nights

Total:

$\$ 1,280.00$

As each of you will be arriving independently, we are unable to provide group transfers to your hotel. We will gladly make arrangements for transfer by private car for an additional fee.

\section{Conference Mailing List}

$\square$ I will register for the 1981 International Conference at a later date. Please send additional conference information and

program materials as they are available.

\section{Pre-Registration Fees}

To receive the lowest "early registration" discounted fee your pre-registration form must be postmarked on or before January 1, 1981. For the regular "pre-registration" discounted fee your form must be postmarked on or before June 1, 1981.

Early Registration

(by January 1, 1981)
Pre-Registration

(by June 1, 1981)

NALLD Member ......\$\$0

NALLD Member ......\$60

Non-Member ........\$\$65

$\square$ Non-Member ..........\$75

\section{On-site Registration}

NALLD Member

Non-Member

Payment

NALLD Membership

$\$ \ldots \ldots \ldots \ldots \ldots \ldots \ldots \ldots \ldots$

Pre-registration fee

TOTAL

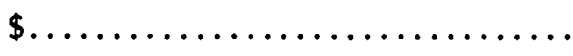

My check or money order for $\$ \ldots . .$. , payable to FLEAT, is enclosed. Refunds will be made only on cancellations received prior to June 15, 1981. Housing forms, information about study trips and other pre-conference and post-conference activities will be sent to you upon receipt of your pre-registration form. The official conference program will be sent to you at least $\mathbf{3 0}$ days prior to the conference.

Return pre-registration form and payment to:

FLEAT Conference Registration

c/o Leslie F. Bailey

Room 48B, Kresge Centennial Hall

Northwestern University

Evanston, Illinois 60201

For further information

FI.EAT Conference

about the conference:

r'o C. P. Richardson

I anguage Laboratory

Ohio University

Athens, Ohio 45701 
THE INTERNATIONAL CONFERENCE ON

AUGUST 18-21, 1981

FOREIGN LANGUAGE EDUCATION

AND TECHNOLOGY (FLEAT)

TOYKO, JAPAN

HOTEL OKURA

YOU CAN SAVE BY SENDING IN YOUR REGISTRATION

BEFORE THE EARLY REGISTRATION DEADLINE OF IANUARY 1, 1981

Conference Badge and Mailing Information

Fill in the information below for preparing your conference badge and for mailing you additional conference materials.

Name:

Title:

Institution:

Street:

City/State/Zip:

Office Phone:

Name of Spouse (if attending conference:)

Note: Spouse is given complimentary registration for the conference.

\section{NALLD Membership Enroliment}

$\square$ Individual member in North America - one year (U.S. \$10)

$\square$ Individual member in North America - three years (U.S. \$30)

(Entitles members to all available back issues of NALLD Journal)

$\square$ Institutional subscribers and all members outside of North America one year (U.S. \$15)

$\square$ Institutional subscribers and all members outside of North America three years (U.S. \$45)

(Entitles members to all available back issues of NALLD Journal)

$\square$ Student membership - one year (U.S. \$5)

$\square$ Sustaining/Business membership - (U.S. \$100)

$\square$ (Entitled to free use of NALLD mailing list)

$\square$ I have not previously belonged to NALLD

\section{CONFERENCE FEATURES}

Special Interest Groups

- Language Journal Editors

- Language groups-teachers of English (ESL), French, German, Chinese, Japanese, Russian, etc.

International Video Festival

- Video presentations from throughout the world used in language learning.

Dinner and Continental Breakfast

General Sessions

- Presentations by world leaders in language education and technology. Sertion Meetings

- Many short presentations related to language education throughout the world. 


\section{Exbibits and Demonstrations}

\section{Sludy Trips}

- Visit schools, colleges, large corporations and other training facilities which feature some of the latest developments in technology.

\section{Special Tours}

- Visit historical and other sights in Japan either before or after the conference.

\section{Spouse Tours}

- Special tours for spouses and families of conference participants to areas in and around Tokyo will take place during the conference.

\section{Transportation to lapan}

- Significantly reduced costs for charter flight from the United States to Japan for those who pre-register.

\section{A CALL FOR PAPERS}

You are invited to participate in the 1981 International Conference on Foreign Language Education and Technology in Tokyo, Japan. As part of the Conference several section meetings will be held in which papers or presentations will be delivered to those attending the conference on topics related to foreign language education and technology. The format of these meetings is to include 20 minutes for each paper or presentation with 10 minutes for questions and discussion following each presentation.

Abstracts of proposed presentations must be submitted for consideration by the Conference Program Committee by November 1, 1980. Early submission of abstracts prior to this date is encouraged.

Abstracts may be submitted on any topic related to language learning, and particularly the use of technology in language learning including future trends and developments. A partial listing of topics which might be considered would include:

auditory comprehension

oral production

reading comprehension

writing

active language performance

$$
(=a+b)
$$

passive language performance

$(=c+d)$

pronunciation

conversation

audio-visual communication

teaching grammatical structures

creative communication

teaching materials

teaching methodology

C A I

Send abstracts to:

\author{
interactive videodisc \\ modern languages \\ standards and formats \\ language and culture \\ testing and evaluation \\ lab instructor training \\ curriculum \\ educational policies \\ psychology of learning \\ lab equipment \\ administration \\ maintenance \\ satellite technology \\ rate controlled recordings \\ use of film and video \\ others \\ FLEAT Conference \\ c/o Joseph H. Sheban \\ Departmbent of English \\ University of Houston \\ Houston, Texas 77004
}

